\title{
GENDER \& TRADE UNIONS DATABASE: A BASIS FOR CHANGE?
}

\author{
Karen Douglas \\ Health and Community Services Union, Victoria, \\ Australia
}

Carol Jess

Victoria Management School

Victoria University of Wellington

\begin{abstract}
This paper proposes that raising awareness of gender deficits in trade union leadership is required to highlight the need for change in trade union leadership and representation, if renewal is to be effective. The writers discuss in particular a project by a research group under the auspices of the Global Labour University to develop an international database on women in trade unions. This database is intended to be both a tool to highlight where change is needed and to measure when, and if, change is made. There is a discussion of the pilot of this database during 2012, and the plans for the future made by the research group.
\end{abstract}

\section{Introduction}

The Gender and Trade Unions Research Group (RG) was established in 2009. It is a grass roots driven alliance between trade union practitioners, trade unionists, practitioners in the broader labour movement, and academics. All the members of the RG are connected to the Global Labour University, which is an ILO supported initiative to bring together academics and activists to further develop labour policy globally. The focus of this $\mathrm{RG}$ is to broaden academic contributions relating to the positioning of women in trade unions and its unique strength lies in the depth of experiences member researchers bring to its academic endeavours. As argued elsewhere '...the researchers are both "insiders" and "outsiders"... [and] ...are actively engaged in labour movements... This unique combination of seemingly contradictory positions provides...a uniquely valuable vantage point as participant observers.' (Britwum, Douglas, Ledwith, 2012)

The group is particularly interested in the positioning of women in trade unions for a number of reasons. Although increasing numbers of women are joining trade unions around the globe, this membership increase is not reflected in trade union leadership positions. As austerity measures are applied globally, women suffer the worst of these measures disproportionately by the loss of jobs and through social welfare cuts. Similarly, as trade unions grapple with the pressures of 21st century economic thinking, elevating the individual over the collective, trade unions are in need of internal change to continue to grow and represent the breadth of membership.
The group has conceived, developed, and plans to implement a database that is specifically designed to track the positioning of women in trade union leadership and other positions of authority. The purpose of the database is to enable researchers to access a data collection point that can provide empirical data of what has and hasn't changed for women in trade unions over time. Its uses are many, however a driving force is to develop trade union consciousness about gender democracy deficits and to consider further action to close the gender gap.

This driving force to develop trade union consciousness about gender has its roots in the Freirian concept of conscienzitacao, and the group's commitment to praxis. The combination of consciousness raising (conscienzitacao) and the translation of theory into practice in order to bring about social change, or praxis, has long been at the heart of feminist academia (Ledwith 2012, 343), and particularly in the work of British female industrial relations academics.

While there has long been an acknowledgement of the "crisis" in the movement, most activists and union leaders spend their working lives dealing with the most proximate, urgent issues - there is not often the luxury of time for reflection on what the union should be and become. Using interactive research methods can allow both academics and activists space to reflect on these issues and perhaps make some progress in strategic thinking.

One early example of the translation of this research into change is where a colleague from Nigeria asked his organisation what was the proportion of female membership in trade unions. There was no data collected 
on this but the peak body will now collect this data purely because the question was asked. (Britwum et al 2012)

The next section of the paper will describe factors contributing to the gender deficit in trade unions through the prism of the standard employment relationship. It will then explore trade union renewal literature and link the need to change trade unions profiles to better reflect membership bases, using women's positioning in trade unions and women focused enterprise bargaining agendas as measurement tools. By way of example, the creation of the database will describe how the gender and trade unions research group exemplifies a successful grass roots alliance between progressive thinkers with a broad and complementary skill set.

\section{Gender and trade union renewal}

\section{Standard employment relationship and enterprise bargaining}

Trade unions have developed in concert with the labour market, which consistently reflects a male breadwinner/ female caregiver role, influenced by a socially constructed gender contract underpinning female and male roles. Similarly, the 'ideal worker' is inextricably linked to the binary construction of gender roles. In the era of globalisation this demands that workers participate in the labour market on equal terms, thus placing a heavy burden on women to combine unpaid, caring work with paid work. Exposing and displacing gender constructions relative to the employment relationship allows an alternative trade union renewal agenda to develop.

The unencumbered worker, who has no domestic or caring responsibilities, is reflected in the 'standard employment relationship', characterised by a male, fulltime employed worker with job security. This has come to be considered the normative worker (Vosko, 2010; Votinius, 2006). This normative worker has enjoyed the benefits of labour law protections, including access to wage setting mechanisms, protection from dismissal, and enjoyment of terms and conditions of employment achieved through bargaining (Chapman, 2005 \& 2006; Vosko, 2006 and 2010). In an industrial setting the impact of this historical construction has been profound. Labour markets have developed over time to construct a division of labour where women are expected to continue to perform domestic roles whilst engaging in the labour market. This dichotomy is more easily identifiable in industrial capitalist economies where 'non-standard' forms of employment, characterised by part-time working arrangements, limited access to the benefits of bargained conditions such as leave arrangements and differing access to income benefits are stark and experienced overwhelmingly by women (Chapman, 2005, pp.87-88; Vosko,2010, pp. 95-100).

Enterprise bargaining has been established around this norm and, given the reliance on negotiations being led by people at the table taking direction from relative constituents, trade unions are more easily influenced by the omnipresent, not necessarily majority, voice. By way of example Chapman, drawing on the work of Berns in the Australian milieu, argues that minimalist parental clauses in collective agreements, coupled with the low uptake of existing parental clauses by men, reinforces the position of the unencumbered worker as the preferred worker in the labour market (Chapman, 2005, pp. 85-88). Whilst this research is specific to the Australian context our research demonstrates, albeit on a smaller scale, that this situation is apparent in other countries.

In addition to skewed enterprise bargaining outcomes, trade unions have relied on the gender construct to argue that women are uninterested in participating in trade union activism and do not want to be organised (Yates, 2006 \& 2010). We aim to offer further research contributing to the breakdown of such constructions and rely on enterprise bargaining as one way of demonstrating change.

Case studies developed by the RG demonstrate that women's industrial needs are achieved by women fighting for specific clauses such as breastfeeding, additional parental leave and menstrual leave (Britwum, Douglas, Ledwith, 2012, pg.57). It is thus imperative that trade unions broaden their approach to bargaining to make enterprise agreements more applicable to an entire workforce with the trade off being that unions make themselves relevant to a larger group of people. In so doing, unions can both contribute to challenging the outcomes of the gender contract currently underpinning traditional thinking and develop bargaining and political agendas that better represent all workers.

\section{Renewal}

Trade union renewal is multifaceted. Trade unions in the 21st century must analyse their organising and bargaining agendas to test their relevancy. Trade union renewal research more recently speaks to a crisis of legitimacy (Dufour \& Hege, 2010; Voss, 2010) being experienced by trade unions and argues that unions need to reflect on internal practices to assess their capacity to genuinely represent the eclectic base of modern day workplaces. In an environment of trade union decline, Dufour and Hege (2010) argue that trade unions continue to organise themselves internally around historical assumptions of labour and thus are not positioning themselves to better reflect modern day workers. Given this premise they argue there are essentially three options available to unions in the current milieu: safeguard their positions by relying on existing legislative protections; increasingly rely on a shrinking group of core workers for leadership; or change (Dufour \& Hege, 2010; Voss, 2010, pg.378).

Voss and Sherman (2000) found that unions were able to successfully revitalise themselves when using a combination of alternative approaches, thus disrupting the '...iron law of oligarchy...' characterised by a conservative bureaucratic approach to decision making and practice in social movements. They concluded three factors influence union's ability to change: internal political crisis; the inclusion of new leaders with broader social movement activist experiences; and international 
union influence encouraging new leaders with broad social movement activist experiences (2000, pg. 309). The authors found that changing internal union demographics resulted in unions actively changing the way they organised workers, resulting in myriad positive political and industrial changes including '...focusing on issues such as dignity and fairness in addition to material concerns...' (2000, pp. 311-312). It is this particular aspect of trade union renewal literature that our research seeks to contribute to in very practical ways. Whilst it is necessary to continually fight against the global gender pay deficit (estimated at 18\% across 48 countries - see note 1 ) it is equally imperative for trade union bargaining agendas to broaden in order to better represent different interests, thus creating the conditions for more inclusive voices and contributing to stronger collective thought and action.

\section{Democracy}

Voss and Sherman conclude that trade unions who actively change their approach to organising are successful in organising previously marginalised groups '...including excluded minority and gender groups...' (2000, pg.313). Creating change by reassessing democratic representative processes within unions is one way of challenging embedded leadership. Iris Marion Young's work on deliberative democracy (1990; 2002) stresses a model of '...inclusive practices' (2002, pg.17) as providing a foundation for developing deeper democratic functioning of organisations. In a trade union context we argue that trade union leaders are in a position to challenge existing practices and actively shift decision making from majority thinking to a broader inclusive approach, thus providing the space for diverse leaderships.

\section{Difference}

In concert with assessing internal democratic practices, renewal agendas can be complemented by practising the 'politics of difference' (Fraser, 2007). While we act to further the cause of greater and better representation of women by our labour movements, we must remain mindful of the problems which may accompany such a strategy. Fraser argues convincingly that simply recognising that women, as a group within trade unions, lack legitimate representation, and working to enhance that representation for women as a group, is unlikely to correct the democratic deficit, and wider economic injustice. The identification of a group, with shared interests and aims which are not so shared by the "mainstream," can also reproduce the democratic deficit by simply creating new "insiders" and "outsiders" within that group of outsiders, while maintaining the position of the group as a whole as one of outsiders

As identified by Ardha Danielie (2006) and discussed by Ledwith (2012), the task is to find ways of acknowledging and attending to both class and gender without merely adding class to gender and gender to class, where "class" refers to Fraser's politics of re-distribution and gender to her politics of difference. The suggestion then is for a framework of 'dual praxis' within industrial relations research.

In a workplace context, or a trade union context, while it is argued that a great majority of the barriers to women's participation and leadership are down to the disproportionate amount of caring and other "invisible" (Franzway \& Fornow 2011) work done by women outside the paid workplace, characterising these responsibilities as women's work and seeking flexible working arrangements become “women's issues”. This only serves to entrench the notion of the unencumbered worker as the norm. This approach includes as "normal" those women who are not parents, or carers, and excludes men who may have primary carer responsibilities, or who may wish to take on caring responsibilities. Further, it does not challenge these myths and does not open the space to find new ways of approaching work/life balance.

This attitude is also heteronormative, and assumes the constitution of "family" as a heterosexual couple with children, and also those with parents who require care.

\section{The relevance for renewal of the "unencumbered worker"}

The recent (and ongoing) dispute at the Ports of Auckland in New Zealand gives some examples of how unions could contribute to their own renewal by exploding the myth of the unencumbered worker, even in areas where the majority of members and possible members are men.

While the media furore surrounding this was very bitter, the main thrust of the public debate was based on the idea of the old-fashioned union protecting its very privileged members against those who would be willing to work, under any terms and conditions, just to have a job. The union did publicly campaign around the idea that even full-time, male breadwinners have a life outside of work, but this argument against casualization in general was totally drowned out by the calls from "business", the Government and a large part of the "public" for union members to relinquish their "privilege" and accept "progress" in order to keep their livelihoods.

The possibility that the workers who were already on casual contracts and those who were going to be made redundant and re-hired on new contracts might be interested in becoming or remaining union members was not raised. Even if there were no likelihood that the new employer would collectively bargain with those employees, including them within the trade union movement would have sent a message to employers about the inclusiveness of the trade union movement.

Increasing numbers of workers worldwide are in such casualised, outsourced work; but while unions fail to adequately represent their current membership in their hierarchies and bargaining positions, they are unlikely to attract other workers who do not fit within their narrowly constructed ideal. Indeed, it may become difficult to maintain the membership levels they currently have.

A substantial, if belated, first step towards a sustainable, and meaningful re-imagining of the "trade union 
member" would be the proportionate representation of women in the leadership of our unions.

\section{Australia \& New Zealand}

The first formal data gathering exercise to assess the positioning of women's roles in trade union is Australia was conducted by the ACTU in 1999. This research was undertaken again in 2010. The data demonstrate that women are joining unions in greater numbers and women's presence in union decision making and leadership roles is increasing however, women's presence in these positions continues to be disproportionate to their membership numbers (ACTU Women's Committee, 2012).

The report reflects upon important changes that have occurred over time and acknowledges the increasing numbers of unions with broader family friendly employment policies encouraging more women in to union work. Further, the research indicates the shifting nature of bargaining agendas to embrace a broader range of industrial matters. Ultimately though, as the employment relationship continues to change rapidly, there remains an absence of diversity in leadership positions.

Cooper (2012) in her qualitative research explores the masculinity of trade union culture. The narratives identify barriers to women's participation and encouragingly indicate an overall shift in the way women are able to operate with union structures. Importantly exposing women's experiences of trade unions in Cooper's research, coupled with the statistical analysis of the ACTU Women's Committee, exposes the good and the bad of trade union culture and provides a platform for further discussion and research.

In New Zealand, in addition to the qualitative academic research available, (see Parker et al 2012 and Cooper 2012 for recent examples) the Human Rights Commission has published a bi-annual Census of Women's' Participation since 2006. This reports on women's leadership in all areas of economic and civil society, and includes trade unions. The 2010 report shows that women continue to be the majority of trade union members, but that there had been a $9.2 \%$ drop in the number of women as national executive members since 2008. The underrepresentation of women in leadership is noted as a problem, particularly since trade union growth is likely to remain reliant on women's unionisation.

\section{Methodology}

This paper has combined traditional academic approaches to developing sound evidence based research with innovative, grass roots practice by drawing on the experiences and contributions of practitioners in the trade union field. This integrated approach provides the space for practising activists to create and contribute to developments in the field whilst simultaneously reporting on outcomes. At its most fundamental, this approach demonstrates the crucial contribution grass roots organising and networking makes to the possibilities available to trade unions to review and consider growth strategies.

\section{Database usage}

The compilation of the database has been carried out, as a pilot, by asking all 15 members of the RG to submit both quantitative and qualitative data on their own trade union organisation - whether that be a local or national trade union, or a trade union confederation. This information was collected by way of an online survey, using the browser-based software Surveymonkey.com. 6 responses were received, a $40 \%$ return. The questionnaire used was adapted for this purpose from the questionnaire previously used in face to face interviews by the RG members in compiling their previous case studies. This was done to provide a link to that previous research, and to ensure consistency as far as possible, given the differing methods of data collection. The draft online survey was firstly circulated to the RG, for feedback on the format, questions, and layout of the questionnaire. After discussion of some comments received, the wording on various questions was changed to clarify the information sought. The updated version of the survey was then circulated to the RG for their completion.

The respondents were asked to give details of the membership of their organisation, the number of office holders, and the numbers of women in the general membership and office holders. Further information was requested on whether and what structures existed to support the development of gender equality - women's committees, affirmative action, etc. Space was left open for the respondent's opinion on the position of these structures, their perception in the "mainstream" and their efficacy in advancing women's inclusion in the organisation in general and leadership in particular.

Data from previous research carried out by the RG, but in a different format, will also be added to the database. This gives us the basis on which to begin tracking changes in the position of women in trade unions across time, as well as space.

As with any survey of self-selected participants there was no attempt to sample the population, or to control for the type of data, and source. We therefore have received two entries for Zambia, although the data is for different organisations. The purpose of this paper, however, is not to show scientific analysis of our data, but to provide an illustration of how such a database may be a valuable tool for researchers - whether academic or activist.

Our first set of static data was downloaded into Excel format, then re-formatted to display meaningful tables comparative as between the entries.

\section{DATA - Leadership}

We first of all looked at the proportion of female members within each organisation, and where women were (or were not) in the leadership of those organisations. Tables 1 and 2 show the responses that were received to this question. 
Of those who had the data, women's membership ranged from $40 \%$ to $77.33 \%$. The proportion of women on the main decision making bodies, however, does not reflect these membership figures. While in Australia women make up $77 \%$ of the Health Services Union membership, they are only $50 \%$ of the membership of the National Council and National Conference; though a good outcome was that $100 \%$ of the delegation to the most recent congress was female.

Of the six entries only Australia and New Zealand could report any female union presidents, though with Gambia these 3 entries reported at least one female vice-president. As previously stated this is not a full exercise in data collection; however, given these responses it appears that even where women are a majority of the membership of our unions they are not represented by the leadership structures in the same proportions.

\section{Data - women's structures}

As discussed above, some successes have been achieved in moving collective bargaining onto gender specific topics through the creation and use of separate women's structures and caucuses. The compilation of data on where and how such structures are used could be a powerful tool in allowing "best practice" to be shared amongst the RG, as well as considering whether there are particular cultural or political issues which may affect the success or otherwise of separate women's spaces within our unions.

The data received from those who responded to these questions is outlined in Table 3.

With regard to the effectiveness, or otherwise, of these structures, the feedback was as follows:

"The effective structures are in practice and the noneffective ones exist just in name in actual sense - they used to be functional but not now."

“The Women's Committee exists in parallel to the main constitutional structures. There is a need for affirmative action to help women take up main constitutional and decision making positions.”

"Due to a lack of annual conferences/congress since 2006 there has generally been a decline in effectiveness in women participation countrywide. Similarly lack of concerted effort to fund women activities in the recent years has also adversely affected women participation. Additionally, there does seem a higher membership turnover rate for women than males due to instances such as dismissals, retrenchments and non merit promotions aimed at weakening the union structures. Women representation on bargaining teams remains a huge challenge despite the deliberate policy to include at least one female member on each team. Women too themselves are often cowed into selecting males to represent them unless the Secretariat interferes in this selection process."”

"Structures do not exist therefore there are no accountability measures to address areas of over and under representation on honorary, elected and appointed positions.” 
Table 1 - Leadership

\begin{tabular}{|c|c|c|c|c|c|c|c|c|c|c|c|c|c|c|}
\hline \multirow[t]{2}{*}{ Country } & \multirow[t]{2}{*}{ Organisation } & \multirow{2}{*}{$\begin{array}{l}\% \\
\text { Women } \\
\text { Members }\end{array}$} & \multicolumn{2}{|c|}{$\begin{array}{l}\text { Membership } \\
\text { Executive }\end{array}$} & National & \multicolumn{3}{|c|}{$\begin{array}{l}\text { Membership on National } \\
\text { Council }\end{array}$} & \multicolumn{3}{|c|}{$\begin{array}{l}\text { Membership on National } \\
\text { Conference }\end{array}$} & \multicolumn{3}{|c|}{$\begin{array}{l}\text { Delegation to most recent } \\
\text { congress }\end{array}$} \\
\hline & & & Total & $\begin{array}{l}\text { of which } \\
\text { Women }\end{array}$ & $\%$ & Total & $\begin{array}{l}\text { of which } \\
\text { Women }\end{array}$ & $\%$ & Total & $\begin{array}{l}\text { of } \\
\text { which } \\
\text { Women }\end{array}$ & $\%$ & Total & $\begin{array}{l}\text { of which } \\
\text { Women }\end{array}$ & $\%$ \\
\hline UK & $\begin{array}{l}\text { UK TU movement, } \\
\text { most taken from Achur, } \\
\text { which includes non- } \\
\text { TUC unions }\end{array}$ & 47.41 & & & & & & & & & & & & \\
\hline Ghana & $\begin{array}{l}\text { Organization of African } \\
\text { Trade Union Unity } \\
\text { (OATUU) }\end{array}$ & & 15 & 3 & 20.00 & 15 & 3 & 20.00 & & & & 6 & 2 & 33.33 \\
\hline ZAMBIA & $\begin{array}{l}\text { ZAMBIA CONGRESS } \\
\text { OF TRADE UNIONS }\end{array}$ & & 10 & 1 & 10.00 & & & & & & & & & \\
\hline Zambia & $\begin{array}{l}\text { Zambia Union of } \\
\text { Financial Institutions } \\
\text { and Allied Workers } \\
\text { (ZUFIAW) }\end{array}$ & 40.00 & 10 & 3 & 30.00 & & & & 150 & 105 & 70.00 & & & \\
\hline Australia & $\begin{array}{l}\text { Health and Community } \\
\text { Services } \\
\text { Victoria }\end{array}$ & 77.33 & 1 & 0 & 0.00 & 8 & 4 & 50.00 & 8 & 4 & 50.00 & 8 & 8 & 100.00 \\
\hline $\begin{array}{l}\text { New } \\
\text { Zealand }\end{array}$ & $\begin{array}{l}\text { Council of Trade Union } \\
\text { affiliates (26) }\end{array}$ & 59.84 & 518 & 176 & 33.98 & & & & & & & & & \\
\hline
\end{tabular}


Table 2 - Leadership (2)

\begin{tabular}{|c|c|c|c|c|c|c|c|c|c|c|c|c|c|c|c|c|c|}
\hline & \multirow{2}{*}{$\begin{array}{c}\% \\
\text { Women } \\
\text { Member } \\
\text { s }\end{array}$} & \multicolumn{2}{|c|}{ President } & \multicolumn{2}{|c|}{$\begin{array}{c}\text { Vice } \\
\text { President }\end{array}$} & \multicolumn{4}{|c|}{ Treasurer } & \multicolumn{2}{|c|}{ General Secretary } & \multicolumn{2}{|c|}{$\begin{array}{l}\text { Assistant } \\
\text { Secretary }\end{array}$} & \multicolumn{2}{|c|}{ Lead Organiser } & \multicolumn{2}{|c|}{ Other } \\
\hline & & Total & Women & $\begin{array}{l}\text { Tota } \\
l\end{array}$ & Women & Total & Women & Elected & Appointed & Total & Women & Total & Women & Total & Women & Total & Women \\
\hline UK & 47.41 & 1 & 0 & N/A & $\mathrm{n} / \mathrm{a}$ & 1 & 0 & 0 & 0 & 1 & 0 & 2 & 2 & 2 & 1 & 0 & 0 \\
\hline Ghana & 0 & 1 & 0 & 7 & 1 & 2 & 0 & 2 & $\mathrm{~N} / \mathrm{a}$ & 1 & 0 & 3 & 0 & 1 & 0 & 0 & 0 \\
\hline $\begin{array}{l}\text { ZAMBI } \\
\text { A }\end{array}$ & & 1 & 0 & 2 & 0 & $\mathrm{~N} / \mathrm{a}$ & $\mathrm{N} / \mathrm{a}$ & N/a & $\mathrm{N} / \mathrm{a}$ & 1 & 0 & 2 & 0 & 1 & 0 & 0 & 0 \\
\hline Zambia & 40 & 1 & 0 & 1 & 0 & $\mathrm{~N} / \mathrm{a}$ & N/a & N/a & $\mathrm{N} / \mathrm{a}$ & 1 & 1 & 2 & 0 & $\mathrm{~N} / \mathrm{a}$ & $\mathrm{N} / \mathrm{a}$ & $5^{1}$ & 2 \\
\hline Australia & 77.33 & 1 & 1 & 2 & 1 & 2 & 2 & 0 & 2 & 1 & 0 & 1 & 0 & 2 & 2 & $2^{2}$ & 2 \\
\hline $\begin{array}{l}\text { New } \\
\text { Zealand }\end{array}$ & 59.84 & 27 & 8 & 31 & 12 & 0 & 0 & 0 & 0 & 26 & 4 & 0 & 0 & 1 & 1 & 0 & 0 \\
\hline
\end{tabular}

\footnotetext{
${ }^{1}$ The role referred to here is "Trustee"

2 The roles referred to here are "Senior Industrial Officers
} 


\section{Table 3 Women's Structures}

\begin{tabular}{|c|c|c|c|c|c|c|c|c|}
\hline & $\begin{array}{l}\text { National } \\
\text { Committee }\end{array}$ & Women's & $\begin{array}{l}\text { National Women's } \\
\text { Conference }\end{array}$ & $\begin{array}{l}\text { Affirmative Action } \\
\text { positions for } \\
\text { National Executive }\end{array}$ & $\begin{array}{l}\text { Affirmative Action } \\
\text { positions for national } \\
\text { Congress/conference }\end{array}$ & $\begin{array}{l}\text { Targets for } \\
\text { women's } \\
\text { representation on } \\
\text { National Executive }\end{array}$ & $\begin{array}{l}\text { Targets for women's } \\
\text { representation at } \\
\text { National } \\
\text { Congress/conference }\end{array}$ & $\begin{array}{lr}\text { Targets for } & \text { women's } \\
\text { representation } & \text { on } \\
\text { workplace bargaining } \\
\text { teams }\end{array}$ \\
\hline Ghana & Yes & & Yes & Yes & Yes & Yes & Yes & No \\
\hline Zambia & Yes & & Yes & No & No & No & No & No \\
\hline Zambia & Yes & & Yes & Yes & Yes & Yes & Yes & Yes \\
\hline Australia & No & & No & No & No & No & No & No \\
\hline
\end{tabular}

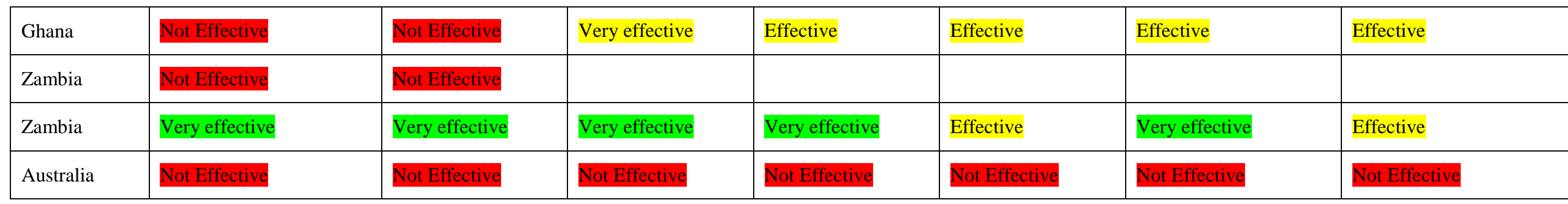




\section{The database in the future}

The database will be updated either bi-annually or annually with the intention of allowing longitudinal study on the gains made by women in the leadership of trade unions in the home countries of those participating in the research. The coverage will be expanded by inviting participation from other GLU alumni; this will both widen and deepen the data available to inform research into gender and trade unions.

It is also hoped that any gaps in the data will flag up space for new research either by the participants in the RG or the wider GLU community. These gaps also create space for activists to press their own organisations to conduct surveys and data gathering on the position of their women.

The database, when fully implemented, will not only take the form of responses to surveys and questionnaires, but should also be a repository for qualitative research papers as well. The RG has already created a unique store of case studies on the subjects of women in trade unions, and also the Bargaining Agenda for Gender based on country and organisation. These papers will also be available within the database, either by directly storing them here, or by linking to them.

Such a vision for the future of the database project will require further investment in developing the IT infrastructure, but once ready should be simple and easy to both update data to and retrieve information from.

\section{Conclusion - Strategy for change}

This research draws on and contributes to trade union renewal literature that demonstrates the false characterisations of the "normal" trade union member and, by disrupting such understandings, looks to contribute to the renewal and growth of trade unions. As discussed earlier, there has been much written on the need for trade union renewal and revitalisation, and looking at the continuing lack of success in increasing the membership and the density of trade union coverage; particularly in the liberal market economies of UK, Australia, New Zealand, and USA there must be a certain acceptance of the crisis of legitimacy put forward by Dufour and Hege (2010).

It is our hope that this database can be used as a concrete basis for activists and academics (and academic activists!) to frame their strategies and policies for change within their unions and federations, those strategies being to further the cause of greater and more relevant representation of the female membership of our unions; and that in turn this change pushes further change within our hierarchies to create space for new membership of our labour movement.

The transnational alliance which has formed in this Research Group, made up of alumni of the Global Labour University must be seen as a particularly sound example of the type of feminist political discourse and space discussed by Franzway \& Fonow (2011) which has opened up allowing its members to engage as transnational political actors, and hopefully to develop themselves and others as the future leaders of the global trade union movement. The existence of the Global Labour University in general, and the Alumni network in particular are valuable spaces for the development of global discourses whose contribution to the push for progressive social policies worldwide should not be diminished.

\section{Notes}

1. ITUC 2012 "Frozen in Time: Gender Pay Gap unchanged for 10 years

\section{References}

ACTU Women's Committee (2012). Women in Australian Unions 2011; Revised May 2012. Available online at http://www.actu.org.au/Publications/Other/Wom eninAustralianUnions2011.aspx

Britwum, A \& Douglas, K, \& Ledwith, S (2012). Women, Gender and Power in Sarah Mosoetsa and Michelle Williams (eds). Labour in the Global South: Challenges and alternatives for workers. ILO, Geneva.

Chapman, A. (2005). 'Work/Family, Australian Labour Law, and the Normative Worker' in Joanne Conaghan and Kerry Rittich (eds), Labour Law, Work, and Family: Critical and Comparative Perspectives ( Oxford University Press, 2005) 7997.

Chapman, A. (2006). 'Regulating Family through Employee Entitlements’ in Christopher Arup et al (eds), Labour Law and Labour Market Regulation: Essays on the Construction, Constitution and Regulation of Labour Markets and Work Relationships (Federation Press, 2006) 454-469.

Cooper, R (2012). The Gender Gap in Union Leadership in Australia: A Qualitative Study Journal of Industrial Relations 54(2) 131-146

Dufour, C. and Hege, A. (2010). The legitimacy of collective actors and trade union renewal. Transfer: European Review of Labour and Research 2010. 16 (3), pp.351 - 367.

Franzway and Fornow (2011). Making Feminist Politics: Alliances between Women and Labour University of Illinois Press, Urbana, Chicago and Springfield.

Fraser, N. (2000). Rethinking recognition. New Left Weekly 3. May - June 
Ledwith, S. (2006). Feminist praxis in a trade union gender project Industrial Relations Journal 37:4, 379-399

Ledwith, S. (2012). Outside, Inside; gender work in industrial relations Equality, Diversity and Inclusion: An International Journal Vol 31, 4 pp340-358

New Zealand Human Rights Commission (2010). New Zealand Census of Womens' Participation 2010 New Zealand Human Rights Commission

Parker, J, Nemani M, Arrowsmith J, \& Bhomwick S. (2012). Contemporary Collective Regulation and Working Women New Zealand Journal of Industrial Relations 54(2) 221-237

Peterson, V. Spike and Runyan, Anne S. (1999). Global Gender Issues, Second Edition. Boulder, CO: Westview Press, 1999.

Voss, K. (2010). Democratic dilemmas: union democracy and union renewal. Transfer: European Review of Labour and Research 2010. 16 (3), pp.369 - 382.

Voss, K. and Sherman, R. (2000). Breaking the iron Law of oligarchy: Union revitalization in the American Labor movement. The American Journal of Sociology. Vol, 106, No.2 (September 2000), pp. $303-349$.

Vosko, L. (2006). Gender, Precarious Work, and the International Labour Code: The Ghost in the ILO Closet. Precarious work, women, and the new economy. The challenge to legal norms. Hart Publishing, Oxford.
Vosko, L. (2010). Managing the Margins: gender, citizenship, and the international regulation of precarious employment. Oxford. Oxford University Press.

Votinius, JJ. (2006). On the Gendered Norm of Standard Employment in a Changing Labour Market. Precarious work, women, and the new economy. The challenge to legal norms. Hart Publishing, Oxford.

Yates, C. (2006). Challenging Misconceptions about Organizing Women into Unions. Gender, Work \& Organization. Vol 13, No.6 (November), pp 565584.

Yates, C. (2010). Understanding caring, organizing women: how framing a problem shapes union. Transfer: European Review of Labour and Research. Vol 16, No.3, pp. $399-410$.

Young, B. (2005). Globalisation and shifting gender governance order (s). In 'So Wi-online (2/2005). Downloaded February 2008 from at www.sowionlinejournal.de/2005-2/globallization_young.htm

Young, I. M. (1990). Justice and the politics of difference. Princeton University Press, New Jersey.

Young, I. M. [2002]. Inclusion and Democracy. Oxford: Oxford University Press, Oxford. Oxford University Press. 


\section{Appendix 1 - Data}

The data collected here has been voluntarily collected by members of the Global Labour University Alumni Research Group on Gender and Trade Unions. It corresponds to information on the organisations to which the group belong. The respondents and the sources of the information input are:

\begin{tabular}{|c|c|c|c|}
\hline Sue Ledwith & UK & $\begin{array}{l}\text { UK TU movement, most taken } \\
\text { from Achur, which includes non- } \\
\text { TUC unions }\end{array}$ & $\begin{array}{l}\text { Nikki Brownlee [2011] } \\
\text { Trader Union } \\
\text { Membership. Dept for } \\
\text { Business, Innovation } \\
\text { and Skills. } \\
\text { www.bis.gov.uk }\end{array}$ \\
\hline $\begin{array}{l}\text { Evelyn Benjamin- } \\
\text { Sampson }\end{array}$ & Ghana & $\begin{array}{l}\text { Organization of African Trade } \\
\text { Union Unity (OATUU) }\end{array}$ & $\begin{array}{l}\text { Annual return. May } \\
2011\end{array}$ \\
\hline BONIFACE PHIRI & ZAMBIA & $\begin{array}{l}\text { ZAMBIA CONGRESS OF } \\
\text { TRADE UNIONS }\end{array}$ & \\
\hline Sylvia Chimpampwe & Zambia & $\begin{array}{l}\text { Zambia Union of Financial } \\
\text { Institutions and Allied Workers } \\
\text { (ZUFIAW) }\end{array}$ & $\begin{array}{l}\text { Membership Data } \\
\text { Verification Exercise - } \\
\text { December } 2011\end{array}$ \\
\hline Karen Douglas & Australia & $\begin{array}{l}\text { Health and Community Services } \\
\text { Union, Victoria }\end{array}$ & $12 / 31 / 2012$ \\
\hline Carol Jess & New Zealand & CTU affiliates (26) & $\begin{array}{l}\text { NZ Human Rights } \\
\text { Commission "New } \\
\text { Zealand Census of } \\
\text { Women's Participation } \\
\text { 2010" }\end{array}$ \\
\hline
\end{tabular}

